\title{
頸椎関節突起骨折の診断と治療
}

\author{
宝金 清博·宮坂 和男*·阿部悟* ·藤谷 正紀 ${ }^{* *} \cdot$ 岩崎 喜信・阿部 弘
}

\section{Fracture of the Articular Process of Cervical Vertebrae}

Diagnosis and Treatment

\author{
Kiyohiro Houkin, Kazuo MiYasaKa*, Satoru Abe*, Masaki FujIYA**, \\ Yoshinobu IWASAKI and Hiroshi ABE \\ Departments of Neurosurgery and *Radiology, Hokkaido University, Sapporo; **Hokkaido Orthopedic \\ Memorial Hospital, Sapporo
}

\begin{abstract}
Fracture of the articular process of a cervical vertebra has received little attention in the literature. This fracture is often overlooked because only a very subtle change is shown in conventional radiological examinations.

In this review of 26 patients with cervical vertebra trauma examined with a high resolution computed tomography (CT) scanner (Somatom II) in the past 3 years, the authors found 6 cases with fracture of the articular process of a cervical vertebra. The diagnosis was mainly based on the very useful findings of CT scan. On the other hand, the plain neck films had less diagnostic value. Some indirect signs, however, such as an anterior subluxation and narrowing of the intervertebral foramen revealed in the plain neck films seemed valuable. The clinical symptoms of this fracture consisted of radicular injury and persistent neck pain. Hyperflexion injury, which seemed to be a notable tendency, was considered as a possible mechanism of this fracture in 2 cases. Anterior fusion was performed in 3 cases and in 3 other cases conservative therapy was continued.

A therapeutic policy for this fracture has not been established. The authors emphasize that both anterior fusion and the removal of the fractured fragment are necessary when anterior subluxation is obvious and the fractured fragment has caused the radicular injury.
\end{abstract}

Key words: spinal injury, articular process, computed tomography

\section{I はじめに}

頸椎関節突起骨折は，頸椎以外の重篤な骨折や猆㖪損傷 をもたらすような重大な外傷に合併することも多いが，と きには単独で生し，軽以上肢の根定状や頸部痛など軽微な 症状のみを示寸こともある。したがって，臨床上単なる頸 筋捻挫などとの鑑別が重要であるが，通常の頸椎単純写真 やX楾断層写真では，ごく軽微な異常所見のみを示寸場 合もあり，その診断が必ずしも容易でないことは多くの報
告が指摘するところである1,9,11,12;.

我々は，過去 3 年間に 6 例の頸椎関節突起骨折を経駼し た。診断に際しては， computed tomography (CT) scan が 有効であったが，頸椎単純写真に打いてもいくつかの興味 ある所見が得られ，診断上，重要と考えられた。また，臨 床症状としては上肢の根症状が多くみられ，その他頑固な 頸部痛や頸部運動制限も認められた。受傷機転上しては， 2 例が明らかに過屈曲損傷によるものであり，注目寸べき 傾向と思われた。治療は，3例において前方固定術が施行

北海道大学脳神経外科 ${ }^{*}$ 同放射線科 ${ }^{* *}$ 北海道整形外科記念病院

Address reprint requests to: K. Houkin, M.D., Department of Neurosurgery, Hokkaido University, North-15, West-7, Kita-ku, Sappora 060. 受稿 1985 年 3 月 4 日 受理 1985 年10月4日 
Table 1 Summary of 6 cases

\begin{tabular}{|c|c|c|c|c|c|}
\hline $\begin{array}{l}\text { Case } \\
\text { No. }\end{array}$ & $\begin{array}{l}\text { Age, } \\
\text { Sex }\end{array}$ & Mechanism of injury & Symptoms & $\begin{array}{l}\text { Site of } \\
\text { fracture }\end{array}$ & Treatment \\
\hline 1 & $46, \mathrm{M}$ & $\begin{array}{l}\text { airplane accident } \\
\text { (hyperflexion) }\end{array}$ & $\begin{array}{l}\text { sensory disturbance of upper limb, } \\
\text { cervical pain }\end{array}$ & $\mathrm{C} 6$ & conservative \\
\hline 2 & $23, F$ & fall (hyperflexion) & $\begin{array}{l}\text { sensory disturbance of upper limb, } \\
\text { ccrvical pain }\end{array}$ & C6 & anterior fusion \\
\hline 3 & $52, \mathrm{~F}$ & $\begin{array}{l}\text { diving injury } \\
\text { (hyperextension) }\end{array}$ & sensory disturbance of upper limb & C6 & conservative \\
\hline 4 & $15, F$ & automobile accident & motor weakness of upper limb & $\mathrm{C} 3$ & anterior fusion \\
\hline 5 & $58, \mathrm{M}$ & automobile accident & $\begin{array}{l}\text { sensory disturbance of upper limb, } \\
\text { cervical pain }\end{array}$ & $\mathrm{C} 6$ & conservative \\
\hline 6 & $37, \mathrm{M}$ & automobile accident & $\begin{array}{l}\text { sensory disturbance of upper limb, } \\
\text { cervical pain }\end{array}$ & $\mathrm{C} 3$ & anterior fusion \\
\hline
\end{tabular}

され，他の 3 例については保存的治療が行われた，本稿に おいては，本症の診断について㛟討し，さらに受傷機転や 臨床像，治療厅針に関しても若干の考察を加えたい。

\section{II 対象}

1981年より1984年 3 月までの約 3 年間に，北海道大学病 院に拈いて高解度力CT scan (Somatom II)による椮查が 施行された頸椎外傷は26例であり、このうち6例に頸椎関 節突起骨折を認めた。今回はこの6 例を対象とし，臨休症 状拉よび受傷機転につき㨢討し，さらに頸椎単純写真， CT scanの所見を比較検討した。

\section{III 結 果}

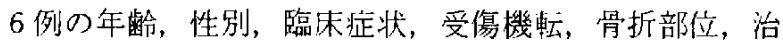
療経過をTable 1 亿示寸。内訳は，男性 3 例，女性 3 例で あり，飛行機の塗落事故, 転落事故の 2 例は明らかに過屈 曲損傷によるものであり，プールへの飛び込み損傷は過伸 展損傷によるものであった，白動車事故の3例流事故の詳 細が不明であり，受傷機転は断定できなからた。臨床症状 としては，6例全例に扔いて患側上肢の知覚障害や筋力低 下などの根症状が認められた。また，頝固な钼部悀，頸部 運動制限など，いわゆるむち打ち損傷の症状も諗められ た。骨折部位は，4例が第 6 頸椎， 2 例は第 3 頸椎であっ た，治療としては，保存的治療(䫡椎カラーによる安静な ど)が 3 例に対して行われ，他の3 例に対しては前方固定 術が施行された。

頸椎単純写真の所見について Table 2 に示す。骨折線の 描出そのものは，斜位像において 6 例中 3 例で諗められた が，必ずしも明睹には認められないものもあった。しか し，前与要脱臼の所見は，側面像において 6 例中 5 例で認 められ，側面像では骨折部の関節面の描出不良も高率に認
Table 2 Summary of the plain neck films findings

\begin{tabular}{|c|c|c|c|c|c|c|c|c|}
\hline \multirow{2}{*}{\multicolumn{2}{|c|}{ Finding }} & \multicolumn{6}{|c|}{ Case No. } & \multirow{2}{*}{$\begin{array}{l}\text { Fre- } \\
\text { quency }\end{array}$} \\
\hline & & 1 & 2 & 3 & 4 & 5 & 6 & \\
\hline \multicolumn{9}{|c|}{ Lateral view } \\
\hline 1. & Anterior subluxation & + & + & - & + & + & + & $5 / 6$ \\
\hline & $\begin{array}{l}\text { Poor visualization } \\
\text { of the facet }\end{array}$ & + & - & + & + & + & + & $5 / 6$ \\
\hline \multicolumn{9}{|c|}{ Oblique view } \\
\hline & $\begin{array}{l}\text { Narrowing or deformity } \\
\text { of the intervertebral } \\
\text { foramen }\end{array}$ & + & + & + & + & - & + & $5 / 6$ \\
\hline 4. & $\begin{array}{l}\text { Visualization of the } \\
\text { line of the fracture }\end{array}$ & + & + & - & - & - & + & $3 / 6$ \\
\hline & $\begin{array}{l}\text { Other accompanying } \\
\text { fracture }\end{array}$ & + & - & + & - & - & - & $2 / 6$ \\
\hline
\end{tabular}

Table 3 Summary of the computed tomography findings

\begin{tabular}{|c|c|c|c|c|c|c|c|c|}
\hline \multirow{2}{*}{\multicolumn{2}{|c|}{ Finding }} & \multicolumn{5}{|c|}{ Case No. } & & \multirow{2}{*}{$\begin{array}{l}\text { Fre- } \\
\text { quency }\end{array}$} \\
\hline & & 1 & 2 & 3 & 4 & 5 & 6 & \\
\hline 1. & $\begin{array}{c}\text { Visualization of the } \\
\text { fracture line }\end{array}$ & + & + & + & + & + & + & $6 / 6$ \\
\hline 2. & $\begin{array}{l}\text { Subluxation } \\
\text { (anterior subluxation, } \\
\text { rotatory subluxation) }\end{array}$ & + & + & - & + & - & + & $4 / 6$ \\
\hline 3. & $\begin{array}{l}\text { Accompanying injury } \\
\text { (other fracture, } \\
\text { disc injury) }\end{array}$ & + & + & + & - & - & + & $4 / 6$ \\
\hline
\end{tabular}

められた，斜位像においては，椎間孔の狭小化や変形な ど，骨折に伴う間接的所見が 6 例中 5 例に認められた。 CT scan 0 听見 Table 3 に示寸。関節突起骨折線は全例 で証明され，診断の根拠となった．前方亜脱臼などの脱臼 については，通常の axial view では不十分で reconstruc- 


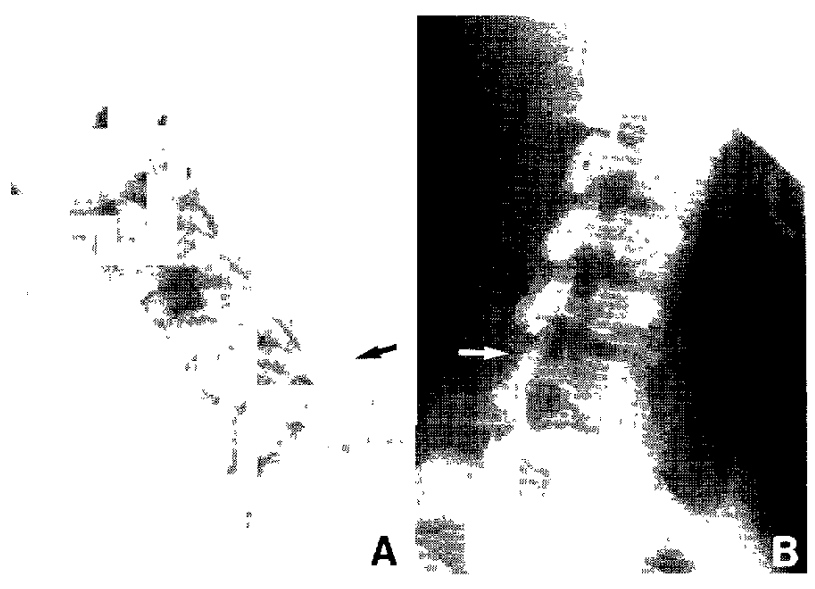

Fıg 1 Plain neck films of Case 2 A. Lateral view shows a localized kyphotic angulation (arrowhead) and fanning of the spinous processes (arrow), which suggest an anterior subluxation at C5/6 $\quad$ B. Oblique view shows a fracture of the superior articular process of the 6th ccrvical vertebra and narrowing of the intervertebral foramen at $\mathrm{C} 5 / 6$ (arrow)

tion viewが必要であり，この尔については単純写真の側 面像のほうがはるかに有效であった。しかし，回旋性里脱 曰曰など特殊な脱臼については，CT scan が有力であった。 また，他の合併損傷(他の骨折，椎間板の損傷など)も CT scanでは明膫に認められた。

以下，代表的な症例を呈示する。

<症例 $2>23$ 才, 女性

主訴：在上肢のしびれ感, 頸部痛

現病歴：1982年10月30日，階段上り伝洛して後向きに倒 れ, 後頭部を打撲し頸部を過屈曲した。 以後, 碩固な頸部 痛と右上肢のしびれ感が出現し，11月9日に入院となった。 神経学的には，右上肢の橈僛の知覚低下と，頸部運動制限 が認められた。

放射線学的検查所見：頸椎単純写真では，側面像で C5/ 6 に怙ける前方亜脱臼が，斜位像では右側 C5/6の椎䦌孔 の狭小化上上関節突起の骨折が認的られた(Fig 1). CT scan では，第6 頸椎の右側の上関節突起の骨折と横突起 骨折が琹められた(Fig. 2).

本怔例では，前方亚脱臼が著しく神経怔状も頙国で市つ たため，C5/6の前方固定術を施行した。

\section{$<$ 症例 $4>15$ 才，女子}

主訴：右上肢の軽い矨力低下

現病歴：1983年11月7日, 自動車にて帰宅途中, 右力一 ブを曲がりきれず車が横転し1回転した，以後, 頸部痛, 両上肢のしびれおよび脱力が出現し，症状は徐々に改善し
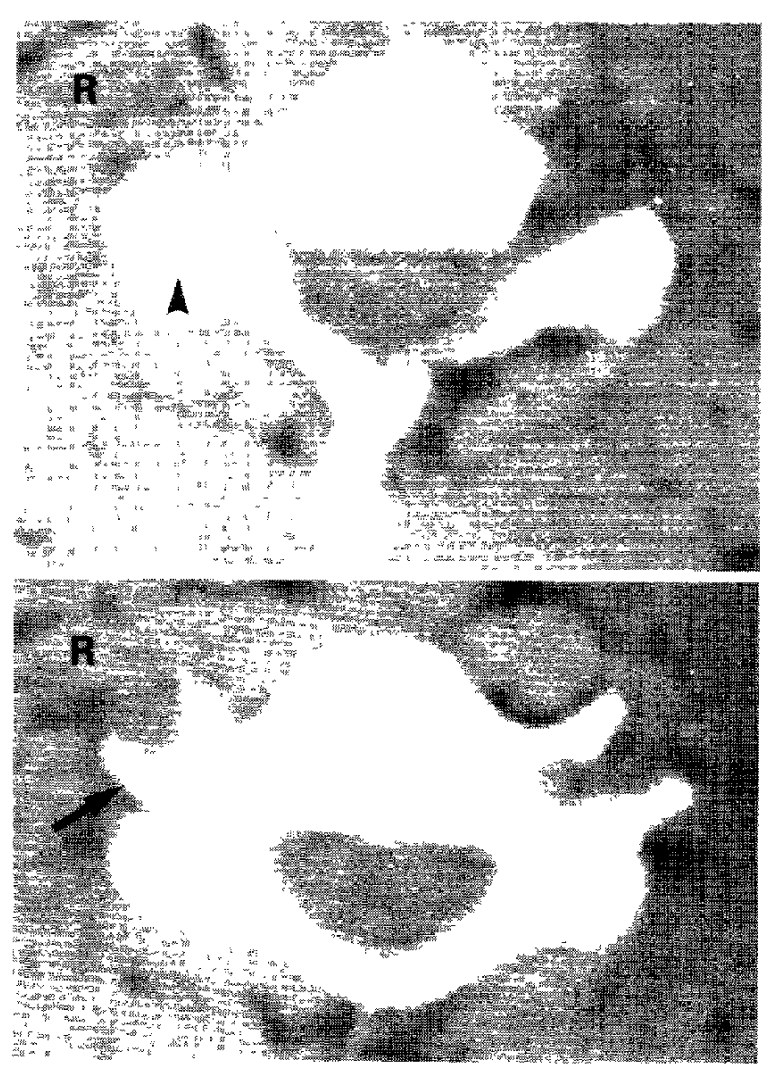

Fig. 2 Computed tomography (CT) scan of Case 2, showing a fracture of the superior articular process (arrowhead) and transverse process (arrow) of the 6th cervical vertebra.

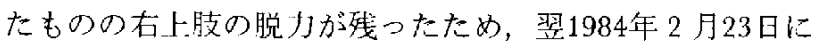
入院となった，神経学的には，右上肢の軽い筋力低下が認 められた。

放射線学的検查所見：頸椎単純写真では，斜位像で $\mathrm{C} 3 /$ 4 にお讨る椎閒孔の变形と第 3 頸椎下関節笑起の変形がみ られたが，肖折線は明らかではなかった(Fig. 3).CT scan では，左側の下閣節突起の骨折が明瞭に認められた( Fig. 4).

本症例でも，前方量脱臼が著しくC3/4k招ける instabilityがあると考え，同部位の前方固定術を施行した。

\section{IV 考察}

外傷後にみられる顓固な頸部痛や上肢の根症状は, 臨休 的にはきわめてよくみられるものであり，しばしば頸筋捻 挫という診断のもとに保存的治療の対象上なっている。 Smith 5 ${ }^{12 i}$ は, この上うな頸椎外傷後の頸部痛の原因疾患 として頸椎関節突起骨折があり，しかもこの疾患は通常の 神経学的检查や放射線学的娭查だけで沙見逃されやすいこ 


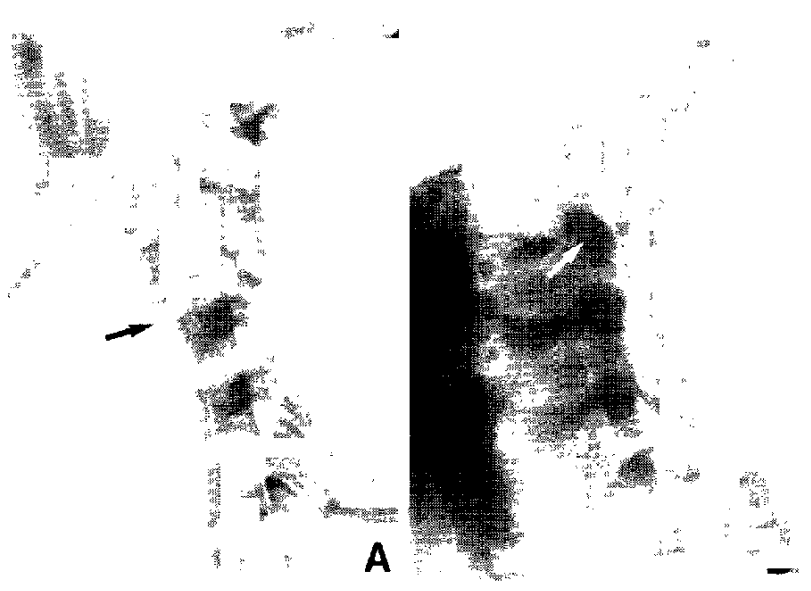

Fig. 3 Plain neck films of Case 4. A: Lateral view shows an anterior subluxation at $\mathrm{C} 3 / 4$ (arrow) and poor visualization of the articular joint (arrowhead). B: Oblique view shows a deformity of the intervertebral foramen at $\mathrm{C} 3 / 4$ (arrow).

$\mathbf{R}$

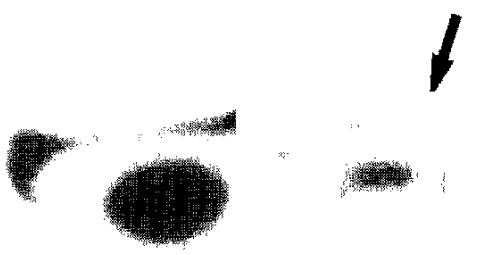

Fig. 4 CT scan of Case 4, showing a fracture of the inferior articular process (arrow) of the 3 rd cervical vertebra.

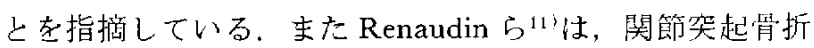
により遊離した骨片が椎間孔を狭小化させるため，椎閒孔 を通る春䯣神経が損傷を受けることを指摘し，関節突起骨 折が上肢の根症状の原因になる上述べている。ささらに， Nieminen $^{9 /}$ が述べているように, 頸椎外傷後の娭查で偶 然に発見されるような無症候のものも多い，我々の6例で は，いずれも䠦床症状を古し，主訴は患側上肢の根症状で あったが，頸部痛を訴えるものも多かった。

頸椎骨折を考元る場合，どうしても受傷機転を考慮しな ければならない2,13). Forsyth ${ }^{3)}$ は，過伸展による shearing stress が関節突起に作用するために同部の骨折が生ずると
し，過伸展損傷の重要性を指摘している。Abel'は， cadaver 考用いて夷験的な関節突起筒折を作製している が，佊らはまず過伸展に上り関節突起の破壊が生じ，次に 過屈曲により前方へのずれが生ずるとし，過屈曲・過伸展 の複合した機転が重要であると述べている。しかし，これ に対してLeeら”は，過屈曲の際に関節突起に過大な生力 が加わり，さらにこの際に回旋の力が作用することにより 一側の関節にこの匹少が集中寸るため，いわゆる flexion shearing の機転が生じ骨折が生ずるとしている，我々の佂 例では，受傷機転が明らかであった 3 例中 2 例が過屈曲撌 傷であった。亦た注日寸べきことは，全例が一側の骨折 で，しかもほとんど前方曲脱目や回旋性亚脱巨寺伴ってい たことである。このことは，やはり Leeらの指摘してい るごとく，回旋の要素を有する過屈曲が，頸椎関節突起骨 折の機転を考えるトで重要であることを示唆していると思 われる。

さて次に，本疾惩の放射線学的㟝断について述べたい， Smith $ら^{12 !}$ は, 项椎単純写真の娭討老行い, 単純与真では 骨折線そのものの描出は困難であることを指摘した上で， その他の問接的所見の重要性を述べている，我々の検客で も，関節突起骨折そのものの描出は，斜位像において半数 の泟例で証明されたが，相当な注意老払っても他の半数の 症例では骨折線は認められなかった。これに対して，側面 像における(1)前方亚脱臼の所見，(2)関節面の描出不良，さ らに斜位像における(3)椎間孔の狭小化や变形，といった関 節突起骨折によって坐ずる間接的所見が，ほとんどすべて

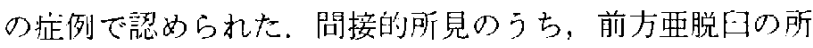
見は比較的容易に発見され，かつ高率に認められるという 点で特に重要と思われた。前方业脱臼の頸椎単純官真での 暗断に関しては，Green ら゙が詳細に述べているが，特に 棘突起問距離の開大(fanning)，亚脱臼レベルにおける局 所的後彎( localized kyphotic angulation)の所見が重要であ る。亦た，椎間孔の変形・狭小化注，斜位像において高率 に認められる所見であるが，これは上関節案起骨折と下関 䬣突起骨折では若下異なる点があり注意を要する。すなわち Renaudin ら"1も指摘しているように，上関節突起骨折で は骨片が椎間孔に向かって動くため，椎間孔の㷋小化が生 じや寸い，椎間孔は，前縁が椎体とLuschka 関節，上下 縁性弓根に上って形成され，後縁は主として上閔節突起 によって形成されているため，上関節突起骨折は直接椎閒 孔の狭小化をむたらし，ひいては神経根怔状も惹起しやす い訳である，これに対して，下関節突起骨折では，骨片は 椎間孔から離れるように後方へ動くこ上が多く, 椎間孔の 狭小化は生じ難く変形程度にとどまり, 神経根症状も軽い ことが多いとされている. Nieminen ${ }^{91}$ は関節突起骨折を 
3つに分類し，下関節宩起骨折では椎間孔の狭小化は生じ 難く，神経症状も軽い上述べている，関節突起骨折に合侀 するその他の肯折に関して，我々の症例では戦純写真上 〈症例 1 〉で横突起骨折が,〈症例 3 〉で椎体の压迫骨折が認 められたが，特に特徽的な所見は認められなかった。しか し，Lee $5^{5}$ はいわ功る tear drop fractureについて詳細な 分析を行い，そのなかで椎体の前_上緑の tear drop fracture 上関節突起骨折は高率に合併すると述べているが，これは 注目寸べき指摘と思われ，この上うな所見も関節突起骨折 在疑わせる間接的所見の一つと思われる。いずれにせよ， 関節突起骨折を直接的に示寸骨片あるいは骨折線の証明 は，頸椎単純写真のみでは困難であり，以上述べてきたよ うな間接的所見を注意深く見い出すことが重要である。

頸椎外傷の診断に扔けるCT $\operatorname{scan}$ の有用性については, すでに多くの㛟討がなされ名10，一般的な有用性に関して はここでは述べる必要はないと思われる. 骨折についても， CT scanの有用性が広く認められているが，それは主上し て複雑な骨折の詳細な分析や合併する椎間板の損傷，瓷椎 管内組織の損傷の分析という観点に集中したきらいがあ り，本腚の上うな非常に軽微な骨折については，まとまっ た報告は認められない，我々の拝例では，単純与真をかな り慎重に読影しても見い出せない上うな軽微な関節突起骨 折が，CT scanでは容易に描出された。充た，微妙な骨折 において，骨折線と鑑別を要するのは関節面の線である が，正確に水平面で得られた像では十分に鑑別が可能であ った。ただし，すでに述べたように前方严脱臼の確認は単 純写真の側面像で十分であり，かつ容易であった，本症の 診断に関して，当然ながら通常のX楾断磨写真の有用性 も認められて拉り, Woodring らも断層写真に上り頸椎骨 折の $20 \%$ 以上に関節突起骨折を証明している は，単純写真の娭討より得られた Miller $ら^{\pi} や A_{\text {Abel }}{ }^{1} の$ 3 11\%という頻度に比べて高く, 断層写真の有用性を示 すものと考えられる. 我々の症例でも数例において断層撮 影を施行しているが，それらはすべて不十分であり検討の 対象とはならなかった。 また, 有䯣造影は本症の診断その ものには特に意味はないと思われるが, 神経泟状の責任病 変の決定には重要であると考えられる，我々の症例でも，

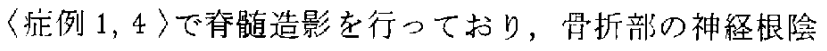
影の描出不良が認奻ら机ている。椎骨動脈撮影は，本症の

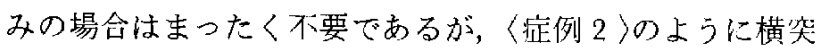
起骨折を合併した場合には考慮する必要がある。

本疾患の治潦方針は，大きく分けて外科的治療と保存的 治療の 2 つに分類される. 我々の症例はいくつかの異なる 施設で治療を受けており, 経過観察期間も短く, 治療方針 に関しては一定の結論は得られていない，他の報告をみて
も，本症の治療方針に関して明確な結論を表明しているも のはない.しかし，Renaudin らいおよび Nieminen ${ }^{9}$ が述 ベているように，椎間孔の狭小化は軽度であり，したがっ て神経根症状も軽微でかつ亜脱臼もないような症例では， 頸部の安静および対㘹的な薬物療法などの保存的治療で十 分であろうと思われる.これに対して，骨片により椎間孔 が狭小化し前力亜脱目の著しい症例では，外科的治療を考 慮しなければならない。この場合, 我々が行ったような単 なる前方固定術により画脱臼部の instability を治療する方 法上, Renaudin ら ${ }^{11}$ や Nieminen"9 の主張寸るような椎間 孔開放と骨片除去を行う方法の 2 つがあると思われる、こ のいずれを選択するかが問題となるが，我々の症例はいず れも前方亜脱臼による instability が著しいため前方固定術 を施行したが，才でに述べたように惟間孔狭小化の著しい 上関節突起骨折などでは骨片除去術の対象上なると考えら れる。しかし，上関節突起骨折にせよ下関節突起骨折にせ よ，前方亜脱臼の明らかな症例では instability 改善さ せ，かつ instabilityがあるために将来生ずると考えられる spondylotic change を防止するためにも，前方固定術虫必 要と考えられる。

\section{V 結 語}

頸椎関節突起骨折の 6 例において㛟討を行った，神経症 状は上肢の根症状, 頸部痛などであり，受傷機転としては 回旋の要素を有する過属曲損傷が重要上思われた。診断に 際しては，CT scanがきわめて有効であり，頸椎単純写真 では診断困難な場合が多かったものの，前方車脱臼や椎間 孔の狭小化などの間接的所見は高率に認められた。治療方 針に関しては今㣪の椮討を要するが，前方固定術あるいは 骨片除去による椎間孔開放術などの外科的治療, および保 存的治療の收捨選択が必要である。

\section{文献}

1) Abel MS: Moderately severe whiplash injuries of the cervical spine and their roentgenographic diagnosis. Clin Orhop 12: $189-$ 208,1958

2) Allen BL Jr, Ferguson RL, Lehmann TR, O'Brien RP: A mechanistic classification of closed indirect fractures and dislocations of the lower cervical spine. Spine 7: 1-27, 1982

3) Forsyth HF: Extension injuries of the cervical spine. J Bone Joint Surg [Amer] 46: 1792-1797, 1964

4) Green JD, Harle TS, Harris JH Jr: Anterior subluxation of the cervical spine: Hyperflexion sprain. AJNR 2: 243-250, 1981

5) Lee C, Kim KS, Rogers LF: Triangle cervical vertebral body fractures: Diagnostic significance. AJR 138: 1123-1132, 1982

6) Maravilla KR, Cooper PR, Sklar FH: The influence of thinsection tomography on the treatment of cervical spine injuries. 
Radiology 127: 131-139, 1978

7) Miller MD, Gehweiler JA, Martinez S, Charlton OP, Daffner RH: Significant new observation on cervical spine trauma. $A J R$ 130; 659-663, 1978

8) Nau HE, Nahser HC, John V: Computed tomographic imaging in cervical vertebral fractures. Surg Neurol 19: 508-512, 1983

9) Nieminen R: Fracture of the articular processes of the lower cervical spine. An analysis of 28 cases treated conservatively. Ann Chir Gynaecol Fenn 63: 204-211, 1974

10) Post MJD, Green RA, Quencer RM, Stokes NA, Callahan RA, Eismont F: The value of computed tomography in spinal trauma. Spine 7: 417-431, 1982

11) Renaudin J, Shyder M: Chip fracture through the superior articular facet with compressive cervical radiculopathy. $J$ Trauma 18: 66-67, 1978

12) Smith GR, Beckley DE, Abel MS: Articular mass fracture: A neglected cause of post-traumatic neck pain. Clin Radinl 27: 335340,1976

13) Whitley JE, Forsyth HF: The classification of cervical spine injuries. AJR 83: 633-644, 1960

14) Woodring $\mathrm{JH}$, Goldstein $\mathrm{SJ}$ : Fractures of the articular process of the cervical spine. AJNR 3: 239-242, 1982

〔別刷請求先: $\mathbf{\top} 060$ 札㹸市北区北15条西 7 丁目, 北海道大学脳 神経外科，宝金清博] 